\title{
Effect of Potassium Levels, Sources and Time of Application on Yield of Onion (Allium cepa L.)
}

\author{
Kumara, B. R., C. P. Mansur, Girish Chander", S. P. Wani*, T. B. Allolli, S. L. Jagadeesh, R. K. \\ Mesta, D. Satish, Shankar Meti, and Sanjeevraddi G. Reddy \\ Department of Horticulture College of Horticulture, UHS, Bagalkot \\ *ICRISAT- International Crops Research Institute for Semi-Arid Tropics, Patancheru, Telangana \\ *Corresponding Author E-mail: kumar.bhavi@gmail.com \\ Received: 5.03.2018 | Revised: 9.04.2018 | Accepted: 15.04.2018
}

\begin{abstract}
The present investigation on "Effect of potassium levels, sources and time of application on yield parameters of onion var. Arka Kalyan" was carried out at the College of Horticulture, Bagalkot, Karnataka during Kharif season of 2015 and 2016. Potassium levels at 200 per cent RDK significantly influenced the polar and equatorial diameter of bulb $(53.80$ and $60.63 \mathrm{~mm}$, respectively), weight of single bulb (105.18 g), bulb yield $\left(20.54 \mathrm{~kg} /\right.$ plot and $\left.48.91 \mathrm{th} \mathrm{ha}^{-1}\right)$ and was on par with 150 and 175 per cent RDK. Among potassium sources, SOP recorded maximum polar and equatorial diameter of bulb (52.09 and $59.80 \mathrm{~mm}$, respectively) over MOP (51.25 and $58.50 \mathrm{~mm}$, respectively). Among potassium sources, SOP recorded significantly higher weight of single bulb and bulb yield per plot and hectare $\left(104.52 \mathrm{~g}, 20.03 \mathrm{~kg} / \mathrm{plot}\right.$ and $45.38 \mathrm{th} \mathrm{ha}^{-1}$ respectively) over MOP $\left(99.96 \mathrm{~g}, 19.06 \mathrm{~kg} /\right.$ plot and $45.38 \mathrm{t} \mathrm{ha} \mathrm{a}^{-1}$ respectively). Significantly higher polar and equatorial diameter of bulb with application of 50 per cent potassium at transplanting and 50 per cent at 30 DAT $(51.96$ and $59.64 \mathrm{~mm}$, respectively) and was significantly superior over application of 100 per cent potassium at transplanting $(51.33$ and $58.64 \mathrm{~mm}$, respectively). The weight of single bulb, bulb yield per plot and hectare was recorded in application of 50 per cent potassium at transplanting and 50 per cent at 30 DAT $(103.54 \mathrm{~g}$, $19.87 \mathrm{~kg}$ and $\left.47.31 \mathrm{tha}^{-1}\right)$ was significantly superior over application of 100 per cent potassium at transplanting $\left(100.94 \mathrm{~g}, 19.20 \mathrm{~kg}\right.$ and $\left.45.74 \mathrm{t} \mathrm{ha}^{-1}\right)$.
\end{abstract}

Key words: Onion, Yield, Potassium, MOP, SOP, Time of Application

\section{INTRODUCTION}

Onion $^{3}$ is one of the important commercial bulbous crops cultivated extensively in India and it belongs to the family Alliaceae. It is a most widely grown and popular crop among the Alliums. The primary centre of origin of onion lies in Central Asia ${ }^{1}$ and the near East and the Mediterranean regions are the secondary centres of origin. It is an ancient crop utilized in medicine, rituals and as a food in Egypt and in India since 600 BC.

Cite this article: Kumara, B.R., Mansur, C.P., Chander, G., Wani, S.P., Allolli, T.B., Jagadeesh, S.L., Mesta, R.K., Satish, D., Meti, S. and G. Reddy, S., Effect of Potassium Levels, Sources and Time of Application on Yield of Onion (Allium cepa L.), Int. J. Pure App. Biosci. 6(2): $540-549$ (2018). doi: http://dx.doi.org/10.18782/2320-7051.6395 
References of onion as food were also found in Bible and Quran. Onion bulb is strongly contracted subterranean shoot with thickened, fleshy leaves as food organ. The bulb is composed of carbohydrates $(11.0 \mathrm{~g})$, proteins $(1.2 \mathrm{~g})$, fibre $(0.6 \mathrm{~g})$, moisture $(86.8 \mathrm{~g})$ and energy (38 cal.), vitamins like ascorbic acid $(11 \mathrm{mg})$, thiamine $(0.08 \mathrm{mg})$, riboflavin $(0.01$ $\mathrm{mg})$ and niacin $(0.2 \mathrm{mg})$ and minerals like phosphorus (39 mg), calcium $(27 \mathrm{mg})$, sodium $(1.0 \mathrm{mg})$, iron $(0.7 \mathrm{mg})$ and potassium $(1.57$ $\mathrm{mg}$ ) per $100 \mathrm{~g}$ edible portion ${ }^{13}$. Onion is mainly used for its flavour and pungency. The component which is responsible for pungency in onion is an alkaloid "Allyl propyl disulphide".

It is a short duration and quick growing crop. In the world, onion is cultivated in 175 countries in 6.7 million acres with an annual production of 47.5 billion tonnes. Leading onion producing countries are China, India, US, Turkey and Pakistan ${ }^{2}$. India is the second largest producer of onion in the world next to china, accounting 22.60 per cent of the world production. In India, onion is being grown in an area of 12.03 lakh ha with the annual production of 194.01 lakh MT and the productivity is $16.10 \mathrm{MT} \mathrm{ha}^{-1}$. Among onion growing states Maharashtra stands first followed by Karnataka, Gujarat, Bihar, Madhya Pradesh, Andhra Pradesh, Rajasthan, Haryana, Uttar Pradesh and Tamil Nadu. In Karnataka, onion is cultivated in an area of 1.36 lakh hectare with production of 20.65 lakh tones and the average productivity is 15.10 $\mathrm{MT} \mathrm{ha}^{-1}{ }^{-2)}$, which is low compared to world average. This illustrates the poor productivity and shelf life of onions produced during kharif. Several factors viz., lack of suitable varieties, poor nutrient management practices and improper storage techniques have been identified as major causes for poor productivity, quality and storability of kharif onion. Onion being semi-perishable crop gets deteriorated during storage, transportation and marketing. Due to storage losses, it cannot be guaranteed that whole amount of the total production is consumed by the people.
The onion is a shallow rooted and potash loving crop, hence it requires fairly higher amount of nutrients including potassium must be maintained in the upper layer of the soil. Generally a heavy dose of fertilizer is recommended for onion cultivation ${ }^{3}$. Like other tuber and root crops, onion is very responsive to potash. Potassium is helpful in many metabolic processes namely production and transport of carbohydrates and sugars, protein synthesis, imparting resistance to pests and diseases, activation of many enzymes, stalk and stem breakage and stress conditions, storage quality, increased bulb size and bulb yield $^{4}$.

Potassium deficiency can bring reduction in production, quality and shelf life of onion. Soils with poor available potassium content usually fail to support satisfactory crop yield $^{5,6}$. Applying sufficient plant nutrients is needed to sustain the higher production in the face of depleting soil fertility status, continuous cropping and reduced arable land area. Compared with most crops, onion is usually quite susceptible to nutrient deficiency because of their shallow and unbranched root system. Thus, it requires optimum nutrition which is very well reflected through positive response to the added fertilizers.

To evaluate the effect of different methods of application, sources, potassium levels on onion crop. In our country, muriate of potash is almost the sole source of potash fertilization which is used by the farmers. But there are some other sources of potash that would perform better than muriate of potash. Keeping in view the significance of above aspects in obtaining higher yields of better quality bulbs. Hence, the present investigation is alarmed with the objectives. To assess the yield parameters of onion to higher graded levels, sources and time of application of potassium.

\section{MATERIAL AND METHODS}

The present investigation on "Effect of potassium levels, sources and time of application on yield parameters of onion var. 
Arka Kalyan" was carried out at the College of Horticulture, Bagalkot, Karnataka during Kharif season of 2015 and 2016. The details of the materials used and the techniques adopted during the investigation are outlined in this chapter. Bagalkot is situated in the Northern Dry Zone (Zone-3) of Karnataka. The centre is located at $75^{\circ} 42^{\prime}$ East longitude and $16^{\circ} 10^{\prime}$ North latitude with an altitude of $542.00 \mathrm{~m}$ above Mean Sea Level (MSL). The district is grouped under arid and semi-arid region with mean annual rainfall of $517.3 \mathrm{~mm}$ and mean temperature of $32.6^{\circ} \mathrm{C}$. The soil of the experimental site was red sandy soil.

\section{Experimental details:}

$\begin{array}{ll}\text { Treatments } & : 20(5 \times 2 \times 2) \\ \text { Design } & : \text { Factorial R.B.D } \\ \text { Replications } & : \text { Three } \\ \text { Season } & : \text { Kharif } \\ \text { Variety } & : \text { Arka Kalyan } \\ \text { Spacing } & : 15 \mathrm{~cm} \times 10 \mathrm{~cm} \\ \text { Plot size } & : 2.1 \mathrm{~m} \times 2.0 \mathrm{~m} \\ \text { Fertilizer dose } & : 125: 75: 125 \mathrm{~kg} \mathrm{NPK} \mathrm{ha-1} \\ \text { Location } & : \text { Haveli farm, COH, Bagalkot } \\ \text { Storage period } & : \text { Three months under ambient condition }\end{array}$

\section{Treatment details:}

Factor I: Levels of potassium

1. $100 \% \mathrm{RDK}+\mathrm{RDNP} \& \mathrm{FYM}\left(\mathrm{K}_{1}\right)$

2. $125 \% \mathrm{RDK}+\mathrm{RDNP} \& \mathrm{FYM}\left(\mathrm{K}_{2}\right)$

3. $150 \% \mathrm{RDK}+\mathrm{RDNP} \& \mathrm{FYM}\left(\mathrm{K}_{3}\right)$

4. $175 \% \mathrm{RDK}+\mathrm{RDNP} \& \mathrm{FYM}\left(\mathrm{K}_{4}\right)$

5. $200 \% \mathrm{RDK}+\mathrm{RDNP} \& \mathrm{FYM}\left(\mathrm{K}_{5}\right)$

Factor II: Sources of potassium: 1. MOP $\left(\mathrm{S}_{1}\right), 2$. $\operatorname{SOP}\left(\mathrm{S}_{2}\right)$

Factor III: Time of application: $1.100 \% \mathrm{~K}$ at transplanting $\left(\mathrm{T}_{1}\right)$

2. $50 \% \mathrm{~K}$ at transplanting and $50 \% \mathrm{~K}$ at $30 \mathrm{DAT}$ $\left(\mathrm{T}_{2}\right)$

Note: Recommended dose of NP @ 125:75 kg and FYM @ $30 \mathrm{t} \mathrm{ha}^{-1}$ was applied commonly to all the treatments and nitrogen was applied $50 \%$ at transplanting and $50 \%$ at 30 days after transplanting.

\section{METERIAL AND METHODS}

1. Bulb yield $\left(\mathbf{k g}\right.$ plot $\left.^{-1}\right)$ : Total yield obtained from the plot was used to calculate the yield of the bulbs in kilograms per plot.
2. Bulb yield $\left(\mathbf{t} \mathbf{h a}^{-1}\right)$ : Bulb yield obtained from the plot was used to calculate the yield of bulbs in tonnes per hectare.

$$
\text { Bulb yield }\left(\mathrm{t} \mathrm{ha}^{-1}\right)=\frac{\text { Area of } 1 \text { ha } \times \text { Bulb yield }\left(\mathrm{kg} \mathrm{plot}^{-1}\right)}{\text { Plot size }\left(4.2 \mathrm{~m}^{2}\right) \times 1000} \times 100
$$

3. Bulb weight (g): The bulbs from ten randomly selected plants were weighted individually on an electronic balance and the average weight of bulb was computed and expressed as grams.

4. Polar diameter (mm): The length between two polar ends of the bulb was recorded with the help of digital vernier caliper and mean diameter was worked out from all the ten bulbs in each treatments. It was expressed in millimeter.

5. Equatorial diameter ( $\mathbf{m m})$ : The diameter at the maximum width of the bulb across the polar length was measured with the help of digital vernier caliper and it was expressed in millimeter.

6. Bulb shape index (B.S.I.) The bulb shape index was worked out by dividing the bulb :length (polar diameter) with bulb width (equatorial diameter).

$$
\text { B. S. I. }=\frac{\text { Polar diameter }}{\text { Equatorial diameter }}
$$

The bulbs with index value 1 was considered as 'globular', those with less than 1 as 'flat' and bulb with a value of more than 1 are considered as 'torpedo'.

7. Split or deformed bulbs (\%): The bulbs having splits or deformed were recorded at the harvest. Then the percentage of splits bulb was worked out for each treatments.

8. Harvest index (\%): The harvest index was calculated by dividing economic (bulb) yield per hectare by total biological yield per hectare on dry weight basis and it was expressed in percentage

$$
\text { Harvest index }(\%)=\frac{\text { Economic yield }\left(\mathrm{t} \mathrm{ha}^{-1}\right)}{\text { Biological yield }\left(\mathrm{t} \mathrm{ha}^{-1}\right)} \times 100
$$




\section{RESULTS}

\section{Yield parameters}

The data recorded on bulb yield ( $\mathrm{kg} / \mathrm{plot})$ in 2015, 2016 and pooled are presented in Table1.

The potassium levels significantly influenced the bulb yield per plot in both the years as well as in pooled data. In pooled data, the higher bulb yield per plot was recorded significantly by $200 \%$ RDK $(20.54 \mathrm{~kg})$ over $100 \%$ and $125 \%$ RDK (18.16 and $19.24 \mathrm{~kg}$, respectively) but was on par with $150 \%$ and 175\% RDK (19.91 and $19.95 \mathrm{~kg}$, respectively).

The bulb yield per plot differed significantly by potassium sources in both the years and in pooled data. Among potassium sources, SOP recorded significantly higher bulb yield per plot $(20.03 \mathrm{~kg})$ over MOP $(19.06 \mathrm{~kg})$.

The bulb yield per plot differed significantly in time of potassium application during both the years as well as in pooled data. Pooled data higher bulb yield per plot was recorded significantly in application of 50\% potassium at transplanting and $50 \%$ at $30 \mathrm{DAT}$ $(19.87 \mathrm{~kg})$ over application of $100 \%$ potassium at transplanting $(19.20 \mathrm{~kg})$.

The potassium levels significantly influenced the bulb yield per hectare in both the years as well as in pooled data (Table 1). In pooled data, the higher bulb yield per hectare was recorded significantly by $200 \%$ RDK (48.91 $\mathrm{t} \mathrm{ha}^{-1}$ ) over $100 \%$ and 125\% RDK (43.23 and $45.82 \mathrm{t} \mathrm{ha}^{-1}$, respectively) but was on par with $150 \%$ and $175 \%$ RDK (47.39 and $47.49 \mathrm{tha}^{-1}$, respectively).

The bulb yield per hectare varied significantly by potassium sources in both the years and in pooled data. Among potassium sources, SOP recorded significantly higher bulb yield per hectare $\left(47.69 \mathrm{tha}^{-1}\right)$ over MOP (45.38 $\left.\mathrm{tha}^{-1}\right)$.

The bulb yield per hectare differed significantly in time of potassium application during both the years as well as in pooled data. In pooled data higher bulb yield per hectare was recorded significantly in application of
$50 \%$ potassium at transplanting and $50 \%$ at 30 DAT (47.31 t ha $\mathrm{ta}^{-1}$ ) over application of $100 \%$ potassium at transplanting $\left(45.74 \mathrm{t} \mathrm{ha}^{-1}\right)$.

The potassium levels influenced the weight of single bulb (g) significantly in both the years and in pooled data (Table 1). In pooled data, the higher weight of single bulb was recorded significantly by $200 \%$ RDK (105.18 g) over $100 \%$ and 125\% RDK (98.27 and $100.71 \mathrm{~g}$, respectively) but was on par with $150 \%$ and $175 \%$ RDK (103.30 and $103.74 \mathrm{~g}$, respectively).

The weight of single bulb differed significantly by potassium sources in both the years as well as in pooled data. Among potassium sources, SOP recorded significantly higher weight of single bulb (104.52 g) over MOP (99.96 g).

The weight of single bulb differed significantly in time of potassium application during both the years and in pooled data. Pooled data showed that, the weight of single bulb recorded in application of 50\% potassium at transplanting and 50\% at 30 DAT (103.54 g) was significantly superior over application of $100 \%$ potassium at transplanting (100.94 g).

The data recorded on polar and equatorial diameter of bulb in 2015, 2016 and pooled are presented in Table 2 .

The potassium levels influenced the polar diameter of bulb significantly in both the years as well as in pooled data. In pooled data, the maximum polar diameter of bulb was recorded significantly by $200 \%$ RDK $(53.80$ $\mathrm{mm}$ ) over $100 \%, 125 \%, 150 \%$ and $175 \%$ RDK (49.29, 51.02, 51.66 and $52.57 \mathrm{~mm}$, respectively) and minimum polar diameter of bulb was recorded with $100 \%$ RDK.

The polar diameter of bulb differed significantly by potassium sources in both the years as well as in pooled data. Among potassium sources, SOP recorded significantly maximum polar diameter of bulb $(52.09 \mathrm{~mm})$ over MOP (51.25 mm).

The polar diameter of bulb differed significantly in time of potassium application during both the years and in pooled data. 
Pooled data showed that polar diameter of bulb recorded in application of $50 \%$ potassium at transplanting and $50 \%$ at 30 DAT (51.96 $\mathrm{mm})$ was significantly superior over application of $100 \%$ potassium at transplanting $(51.33 \mathrm{~mm})$.

The potassium levels influenced the equatorial diameter of bulb significantly in both the years as well as in pooled data. In pooled data, the maximum equatorial diameter of bulb was recorded significantly by $200 \%$ RDK (60.63 mm) over 100\%, 125\% and 150\% RDK (57.25, 58.46 and $58.96 \mathrm{~mm}$, respectively) but was on par with $175 \%$ RDK $(60.44 \mathrm{~mm})$ and minimum equatorial diameter of bulb was recorded with $100 \%$ RDK.

Equatorial diameter of bulb differed significantly by potassium sources in both the years and in pooled data. Among potassium sources, SOP recorded significantly maximum equatorial diameter of bulb $(59.80 \mathrm{~mm})$ over MOP (58.50 mm).

The equatorial diameter of bulb differed significantly in time of potassium application during both the years and in pooled data. Pooled data the maximum equatorial diameter of bulb recorded with application of $50 \%$ potassium at transplanting and $50 \%$ at 30 DAT $(59.64 \mathrm{~mm})$ was significantly superior over application of $100 \%$ potassium at transplanting (58.64 mm).

The potassium levels did not influenced significantly on bulb shape index in both the years as well as in pooled data (Table 2). In pooled data, maximum bulb shape index was recorded by $200 \%$ RDK (0.89) over $100 \%, 125 \%, 150 \%$ and $175 \%$ RDK $(0.86$, $0.87,0.88$ and 0.87 , respectively) and minimum bulb shape index was recorded with $100 \%$ RDK.

The potassium levels did not differ significantly the split bulbs in both the years (Table 3). In pooled data minimum split bulbs was recorded significantly by $100 \%$ RDK $(8.72 \%)$ over $150 \%, 175 \%$ and $200 \%$ RDK $(13.13,12.08$ and $11.95 \%$, respectively) but was on par with $125 \%$ RDK (10.81\%).
Split bulbs did not differ significantly by potassium sources in both the years and in pooled data. Among potassium sources, SOP recorded maximum split bulbs (11.54\%) over MOP (11.13\%).

The potassium levels influenced the harvest index significantly in both the years as well as in pooled data (Table 3 ). In pooled data, the maximum harvest index was recorded significantly by $100 \%$ RDK $(86.80 \%)$ over $150 \%, 175 \%$ and $200 \%$ RDK $(85.81,84.56$ and $82.98 \%$, respectively) but it was on par with $125 \%$ RDK (86.27\%).

Harvest index did not differ significantly by potassium sources and time of application in both the years and in pooled data.

Interaction effects of potassium levels, sources and time of potassium application on harvest index did not differ significantly during both years and in pooled data.

\section{DISCUSSION}

Soil fertility is a major factor in crop production and farmers rely more on chemical fertilizers to increase the soil fertility and productivity. Potassium is the important nutrient, which governs growth, yield and quality. Thus the optimum dose of potassium, sources of potassium and time of $\mathrm{K}$ application is essential for onion to attain its yield potential. The yield depends on yield components, which ultimately depends upon the growth attributes. The practical way of judging the efficiency of all the treatments in an experiment is to comparing the significance of yield variations. In the present investigation on pooled basis.

The bulb yield was increased mainly because of a positive association between yield and yield contributing characters like polar and equatorial diameter of bulb and bulb weight.

Application of potassium levels of 200 per cent RDK significantly influenced the polar and equatorial diameter of bulb, weight of bulb, bulb yield per plot and yield per hectare when compared to 100 per cent RDK. 
This increase in bulb diameter, weight of bulb and bulb yield with different levels of potassium is the result of better performance of plant with respect to growth parameters like plant height, leaf length, leaf area per plant and biomass accumulation.

Potassium levels at 200 per cent RDK significantly influenced the polar and equatorial diameter of bulb (53.80 and 60.63 $\mathrm{mm}$, respectively), weight of single bulb $(105.18 \mathrm{~g})$, bulb yield $(20.54 \mathrm{~kg} /$ plot and 48.91 $\mathrm{t} \mathrm{ha}^{-1}$ ) and was on par with 150 and 175 per cent RDK. The higher bulb yield and yield attributes may be due to beneficial effect of potassium levels on growth parameters. Potassium is important major nutrient of onion which favourably influence the protein synthesis, carbohydrate metabolism and ultimately translocation and storage food material in onion bulb. Further, increase in bulb yield was probably due to increased uptake of nutrients, which might have enhanced the photosynthesis and translocation of photosynthates to the bulb, the storage organ of the onion which ultimately increased the bulb yield of onion. These results are in accordance with the earlier findings of 7,8,9 and10.

The yield and yield parameters differed significantly by potassium sources. Among potassium sources, SOP recorded maximum polar and equatorial diameter of bulb (52.09 and $59.80 \mathrm{~mm}$, respectively) over MOP (51.25 and $58.50 \mathrm{~mm}$, respectively). Among potassium sources, SOP recorded significantly higher weight of single bulb and bulb yield per plot and hectare (104.52 g, $20.03 \mathrm{~kg} /$ plot and $45.38 \mathrm{t} \mathrm{ha}^{-1}$ respectively) over MOP (99.96 g, $19.06 \mathrm{~kg} /$ plot and $45.38 \mathrm{t}$ $\mathrm{ha}^{-1}$ respectively). This may be due to application of potassium sources i.e sulphate of potash resulted in better growth of plant in relation to all growth parameters and more accumulation photosynthates into bulbs and increased the diameter of bulb. Sulphur and potassium are important nutrient for onion they have favourable effect on protein synthesis, carbohydrate metabolism and ultimately stored food material of onion. The SOP might have increased the dry matter production and translocation of photosynthates. Both potassium and sulphur, being the important constituent of plant nutrients might have played major role in carbohydrates metabolism. Moreover, ${ }^{11}$ and 12 have reported increase in yield with increasing level of potassium sulphate application.

The bulb yield and yield parameters differed significantly with time of potassium application. Significantly higher polar and equatorial diameter of bulb with application of 50 per cent potassium at transplanting and 50 per cent at 30 DAT (51.96 and $59.64 \mathrm{~mm}$, respectively) and was significantly superior over application of 100 per cent potassium at transplanting (51.33 and $58.64 \mathrm{~mm}$, respectively). The weight of single bulb, bulb yield per plot and hectare was recorded in application of 50 per cent potassium at transplanting and 50 per cent at 30 DAT (103.54 g, $19.87 \mathrm{~kg}$ and $47.31 \mathrm{t} \mathrm{ha}^{-1}$ ) was significantly superior over application of 100 per cent potassium at transplanting $(100.94 \mathrm{~g}$, $19.20 \mathrm{~kg}$ and $45.74 \mathrm{t} \mathrm{ha}^{-1}$ ).

The result indicated that the yield and yield parameters increased with 50 per cent potassium at transplanting and 50 per cent $\mathrm{K}$ at 30 DAT. It is known that potash helps in root development and increases the efficiency of leaf in manufacturing sugars and starch. Though split application, potash is likely to be utilized by the crop more efficiently and help to form bigger bulbs, bulb weight and bulb yield due to split application of potash. These findings are in agreement with the results of $13,14,15$.

Interaction effects of potassium levels, sources and time of application on bulb yield and yield parameters did not differ significantly during both years as well as in pooled data. 
Table 1: Bulb yield and weight of single bulb of onion var. Arka Kalyan as influenced by the soil application of potassium levels, sources and time of application during kharif season

\begin{tabular}{|c|c|c|c|c|c|c|c|c|c|}
\hline \multirow{3}{*}{ Treatment } & \multicolumn{9}{|c|}{ Yield parameters } \\
\hline & \multicolumn{3}{|c|}{ Bulb yield (kg plot ${ }^{-1}$ ) } & \multicolumn{3}{|c|}{ Bulb yield (t ha ${ }^{-1}$ ) } & \multicolumn{3}{|c|}{$\begin{array}{l}\text { Weight of single bulb } \\
\text { (g) }\end{array}$} \\
\hline & 2015 & 2016 & Pooled & 2015 & 2016 & Pooled & 2015 & 2016 & Pooled \\
\hline \multicolumn{10}{|l|}{ Potassium levels (k) } \\
\hline $\mathrm{K}_{1}-100 \% \mathrm{RDK}$ & 15.14 & 21.17 & 18.16 & 36.05 & 50.41 & 43.23 & 94.27 & 102.28 & 98.27 \\
\hline $\mathrm{K}_{2}-125 \% \mathrm{RDK}$ & 15.75 & 22.74 & 19.24 & 37.49 & 54.15 & 45.82 & 95.82 & 105.60 & 100.71 \\
\hline $\mathrm{K}_{3}-150 \% \mathrm{RDK}$ & 16.30 & 23.51 & 19.91 & 38.82 & 55.97 & 47.39 & 98.85 & 107.76 & 103.30 \\
\hline $\mathrm{K}_{4}-175 \% \mathrm{RDK}$ & 16.48 & 23.41 & 19.95 & 39.24 & 55.75 & 47.49 & 98.86 & 108.61 & 103.74 \\
\hline $\mathrm{K}_{5}-200 \% \mathrm{RDK}$ & 16.95 & 24.13 & 20.54 & 40.36 & 57.45 & 48.91 & 101.53 & 108.83 & 105.18 \\
\hline S.Em \pm & 0.32 & 0.26 & 0.23 & 0.76 & 0.62 & 0.54 & 1.11 & 1.44 & 0.89 \\
\hline C.D. $(p=0.05)$ & 0.91 & 0.75 & 0.65 & 2.17 & 1.78 & 1.55 & 3.18 & 4.12 & 2.54 \\
\hline \multicolumn{10}{|l|}{ Potassium sources $(\mathrm{S})$} \\
\hline $\mathrm{S}_{1}-$ Muriate of potash (MOP) & 15.72 & 22.40 & 19.06 & 37.43 & 53.32 & 45.38 & 94.80 & 105.11 & 99.96 \\
\hline$S_{2^{-}}$Sulphate of potash (SOP) & 16.47 & 23.59 & 20.03 & 39.21 & 56.17 & 47.69 & 100.92 & 108.11 & 104.52 \\
\hline S.Em \pm & 0.20 & 0.17 & 0.14 & 0.48 & 0.39 & 0.34 & $\mathbf{0 . 7 0}$ & 0.91 & 0.56 \\
\hline C.D. $(p=0.05)$ & 0.58 & 0.47 & 0.41 & 1.37 & 1.13 & 0.98 & 2.01 & 2.60 & 1.61 \\
\hline \multicolumn{10}{|l|}{ Time of application (T) } \\
\hline $\mathrm{T}_{1^{-}}-100 \% \mathrm{~K}$ a transplanting & 15.78 & 22.63 & 19.20 & 37.46 & 53.88 & 45.74 & 96.63 & 105.25 & 100.94 \\
\hline $\begin{array}{c}\mathrm{T}_{2}-50 \% \mathrm{k} \text { at transplanting } \& \\
50 \% \mathrm{~K} \text { at } 30 \mathrm{DAT}\end{array}$ & 16.39 & 23.35 & 19.87 & 39.03 & 55.60 & 47.31 & 99.09 & 107.97 & 103.54 \\
\hline S.Em \pm & 0.20 & 0.17 & 0.14 & 0.48 & 0.39 & 0.34 & 0.70 & 0.91 & 0.56 \\
\hline C.D. $(p=0.05)$ & 0.58 & 0.47 & 0.41 & 1.37 & 1.13 & 0.98 & 2.01 & 2.60 & 1.61 \\
\hline \multicolumn{10}{|l|}{ Interactions } \\
\hline $\mathrm{K}_{1} \mathrm{~S}_{1} \mathrm{~T}_{1}$ & 14.59 & 19.55 & 17.07 & 34.73 & 46.56 & 40.64 & 90.33 & 100.63 & 95.48 \\
\hline $\mathrm{K}_{1} \mathrm{~S}_{1} \mathrm{~T}_{2}$ & 15.18 & 20.88 & 18.03 & 36.13 & 49.72 & 42.93 & 91.40 & 101.97 & 96.68 \\
\hline $\mathrm{K}_{1} \mathrm{~S}_{2} \mathrm{~T}_{1}$ & 14.76 & 21.89 & 18.32 & 35.14 & 52.11 & 43.63 & 97.33 & 102.03 & 99.68 \\
\hline $\mathrm{K}_{1} \mathrm{~S}_{2} \mathrm{~T}_{2}$ & 16.04 & 22.36 & 19.20 & 38.19 & 53.24 & 45.71 & 98.00 & 104.47 & 101.23 \\
\hline $\mathrm{K}_{2} \mathrm{~S}_{1} \mathrm{~T}_{1}$ & 15.09 & 22.24 & 18.66 & 35.92 & 52.94 & 44.43 & 95.87 & 103.87 & 99.87 \\
\hline $\mathrm{K}_{2} \mathrm{~S}_{1} \mathrm{~T}_{2}$ & 15.58 & 22.44 & 19.01 & 37.10 & 53.43 & 45.26 & 95.80 & 105.37 & 100.58 \\
\hline $\mathrm{K}_{2} \mathrm{~S}_{2} \mathrm{~T}_{1}$ & 15.81 & 22.79 & 19.30 & 37.63 & 54.27 & 45.95 & 96.33 & 105.13 & 100.73 \\
\hline $\mathrm{K}_{2} \mathrm{~S}_{2} \mathrm{~T}_{2}$ & 16.51 & 23.50 & 20.01 & 39.32 & 55.95 & 47.64 & 95.27 & 108.03 & 101.65 \\
\hline $\mathrm{K}_{3} \mathrm{~S}_{1} \mathrm{~T}_{1}$ & 15.74 & 22.52 & 19.13 & 37.50 & 53.63 & 45.47 & 91.40 & 106.53 & 98.97 \\
\hline $\mathrm{K}_{3} \mathrm{~S}_{1} \mathrm{~T}_{2}$ & 15.59 & 23.60 & 19.59 & 37.15 & 56.20 & 46.68 & 95.33 & 108.10 & 101.72 \\
\hline $\mathrm{K}_{3} \mathrm{~S}_{2} \mathrm{~T}_{1}$ & 16.52 & 23.91 & 20.21 & 39.37 & 56.93 & 48.15 & 101.00 & 105.77 & 103.38 \\
\hline $\mathrm{K}_{3} \mathrm{~S}_{2} \mathrm{~T}_{2}$ & 17.37 & 23.99 & 20.68 & 41.29 & 57.11 & 49.20 & 107.67 & 110.63 & 109.15 \\
\hline $\mathrm{K}_{4} \mathrm{~S}_{1} \mathrm{~T}_{1}$ & 16.19 & 22.14 & 19.17 & 38.55 & 52.71 & 45.63 & 93.20 & 104.07 & 98.63 \\
\hline $\mathrm{K}_{4} \mathrm{~S}_{1} \mathrm{~T}_{2}$ & 16.95 & 23.76 & 20.35 & 40.35 & 56.56 & 48.46 & 94.05 & 108.67 & 101.36 \\
\hline $\mathrm{K}_{4} \mathrm{~S}_{2} \mathrm{~T}_{1}$ & 16.32 & 23.88 & 20.10 & 38.87 & 56.85 & 47.86 & 98.73 & 109.43 & 104.08 \\
\hline $\mathrm{K}_{4} \mathrm{~S}_{2} \mathrm{~T}_{2}$ & 16.45 & 23.88 & 20.17 & 39.18 & 56.86 & 48.02 & 109.47 & 112.27 & 110.87 \\
\hline $\mathrm{K}_{5} \mathrm{~S}_{1} \mathrm{~T}_{1}$ & 16.02 & 2.85 & 19.44 & 38.15 & 54.41 & 46.28 & 99.47 & 105.00 & 102.23 \\
\hline $\mathrm{K}_{5} \mathrm{~S}_{1} \mathrm{~T}_{2}$ & 16.57 & 23.97 & 20.27 & 39.44 & 57.06 & 48.25 & 101.20 & 106.94 & 104.07 \\
\hline $\mathrm{K}_{5} \mathrm{~S}_{2} \mathrm{~T}_{1}$ & 17.17 & 24.53 & 20.85 & 40.88 & 58.41 & 49.64 & 102.64 & 110.07 & 106.35 \\
\hline $\mathrm{K}_{5} \mathrm{~S}_{2} \mathrm{~T}_{2}$ & 18.04 & 25.17 & 21.61 & 42.96 & 59.93 & 51.45 & 102.80 & 113.30 & 108.05 \\
\hline S.Em \pm & 0.64 & 0.52 & 0.45 & 1.51 & 1.24 & 1.08 & 2.22 & 2.88 & 1.78 \\
\hline C.D. $(p=0.05)$ & NS & NS & NS & NS & NS & NS & NS & NS & NS \\
\hline
\end{tabular}

DAT - Days after transplanting, NS-Non significant.

Note: Recommended dose of $\mathrm{N}: \mathrm{P}$ at $125: 75 \mathrm{~kg}$ and farmyard manure $30 \mathrm{t} \mathrm{ha}^{-1}$ was applied commonly to all the treatments and nitrogen was applied $50 \%$ at transplanting and $50 \%$ at 30 DAT. 
Table 2: Polar and equatorial diameter and bulb shape index of onion var. Arka Kalyan as influenced by the soil application of potassium levels, sources and time of application during $k$ harif season

\begin{tabular}{|c|c|c|c|c|c|c|c|c|c|}
\hline \multirow{3}{*}{ Treatment } & \multicolumn{9}{|c|}{ Yield parameters } \\
\hline & \multicolumn{3}{|c|}{ Polar diameter (mm) } & \multicolumn{3}{|c|}{$\begin{array}{c}\text { Equatorial diameter } \\
(\mathbf{m m})\end{array}$} & \multicolumn{3}{|c|}{ Bulb shape index } \\
\hline & 2015 & 2016 & Pooled & 2015 & 2016 & Pooled & 2015 & 2016 & Pooled \\
\hline \multicolumn{10}{|l|}{ Potassium levels (k) } \\
\hline $\mathrm{K}_{1}-100 \% \mathrm{RDK}$ & 47.34 & 51.24 & 49.29 & 56.16 & 58.34 & 57.25 & 0.84 & 0.88 & 0.86 \\
\hline $\mathrm{K}_{2}-125 \% \mathrm{RDK}$ & 49.63 & 52.42 & 51.02 & 57.46 & 59.47 & 58.46 & 0.86 & 0.88 & 0.87 \\
\hline $\mathrm{K}_{3}-150 \% \mathrm{RDK}$ & 50.01 & 53.32 & 51.66 & 57.91 & 60.01 & 58.96 & 0.86 & 0.89 & 0.88 \\
\hline $\mathrm{K}_{4}-175 \% \mathrm{RDK}$ & 50.56 & 54.58 & 52.57 & 58.79 & 62.09 & 60.44 & 0.86 & 0.88 & 0.87 \\
\hline $\mathrm{K}_{5}-200 \% \mathrm{RDK}$ & 51.96 & 55.63 & 53.80 & 59.58 & 61.67 & 60.63 & 0.87 & 0.90 & 0.89 \\
\hline S.Em \pm & 0.42 & 0.23 & 0.23 & 0.51 & 0.40 & 0.31 & 0.01 & 0.01 & 0.01 \\
\hline C.D. $(p=0.05)$ & 1.19 & 0.67 & 0.66 & 1.46 & 1.15 & 0.87 & NS & NS & NS \\
\hline \multicolumn{10}{|l|}{ Potassium sources (S) } \\
\hline $\mathrm{S}_{1}-$ Muriate of potash (MOP) & 49.51 & 52.99 & 51.25 & 57.51 & 59.48 & 58.50 & 0.86 & 0.89 & 0.88 \\
\hline $\mathrm{S}_{2-}$ Sulphate of potash (SOP) & 50.29 & 53.89 & 52.09 & 58.45 & 61.15 & 59.80 & 0.86 & 0.88 & 0.87 \\
\hline S.Em \pm & 0.26 & 0.15 & 0.15 & 0.32 & 0.25 & 0.19 & 0.01 & 0.01 & 0.01 \\
\hline C.D. $(p=0.05)$ & 0.75 & 0.42 & 0.42 & 0.92 & 0.73 & 0.55 & NS & NS & NS \\
\hline \multicolumn{10}{|l|}{ Time of application (T) } \\
\hline $\mathrm{T}_{1^{-}} 100 \% \mathrm{~K}$ at transplanting & 49.45 & 53.21 & 51.33 & 57.35 & 59.92 & 58.64 & 0.85 & 0.88 & 0.87 \\
\hline $\begin{array}{l}\mathrm{T}_{2^{-}} 50 \% \mathrm{k} \text { at transplanting \& } \\
50 \% \mathrm{~K} \text { at } 30 \mathrm{DAT}\end{array}$ & 50.34 & 53.66 & 51.96 & 58.59 & 60.69 & 59.64 & 0.85 & 0.88 & 0.87 \\
\hline S.Em \pm & 0.26 & 0.15 & 0.15 & 0.32 & 0.25 & 0.19 & 0.01 & 0.01 & 0.01 \\
\hline C.D. $(p=0.05)$ & 0.75 & 0.42 & 0.42 & 0.92 & 0.73 & 0.55 & NS & NS & NS \\
\hline \multicolumn{10}{|l|}{ Interactions } \\
\hline $\mathrm{K}_{1} \mathrm{~S}_{1} \mathrm{~T}_{1}$ & 46.91 & 50.43 & 48.67 & 55.34 & 57.21 & 56.27 & 0.85 & 0.88 & 0.87 \\
\hline $\mathrm{K}_{1} \mathrm{~S}_{1} \mathrm{~T}_{2}$ & 47.26 & 51.33 & 49.30 & 56.08 & 57.92 & 57.00 & 0.84 & 0.89 & 0.87 \\
\hline $\mathrm{K}_{1} \mathrm{~S}_{2} \mathrm{~T}_{1}$ & 47.01 & 51.37 & 49.19 & 56.08 & 58.46 & 57.27 & 0.84 & 0.88 & 0.86 \\
\hline $\mathrm{K}_{1} \mathrm{~S}_{2} \mathrm{~T}_{2}$ & 48.16 & 51.84 & 50.00 & 57.17 & 59.76 & 58.46 & 0.84 & 0.87 & 0.86 \\
\hline $\mathrm{K}_{2} \mathrm{~S}_{1} \mathrm{~T}_{1}$ & 48.20 & 52.02 & 50.11 & 57.06 & 58.35 & 57.71 & 0.84 & 0.89 & 0.87 \\
\hline $\mathrm{K}_{2} \mathrm{~S}_{1} \mathrm{~T}_{2}$ & 49.86 & 52.37 & 51.11 & 57.42 & 58.92 & 58.17 & 0.87 & 0.89 & 0.88 \\
\hline $\mathrm{K}_{2} \mathrm{~S}_{2} \mathrm{~T}_{1}$ & 49.82 & 52.59 & 51.20 & 56.84 & 60.09 & 58.46 & 0.88 & 0.88 & 0.88 \\
\hline $\mathrm{K}_{2} \mathrm{~S}_{2} \mathrm{~T}_{2}$ & 50.62 & 52.71 & 51.66 & 58.53 & 60.50 & 59.51 & 0.87 & 0.87 & 0.87 \\
\hline $\mathrm{K}_{3} \mathrm{~S}_{1} \mathrm{~T}_{1}$ & 49.31 & 52.92 & 51.11 & 56.61 & 59.00 & 57.81 & 0.87 & 0.90 & 0.89 \\
\hline $\mathrm{K}_{3} \mathrm{~S}_{1} \mathrm{~T}_{2}$ & 50.30 & 53.17 & 51.73 & 58.07 & 57.72 & 58.90 & 0.87 & 0.89 & 0.88 \\
\hline $\mathrm{K}_{3} \mathrm{~S}_{2} \mathrm{~T}_{1}$ & 49.83 & 53.47 & 51.65 & 57.50 & 59.99 & 58.75 & 0.87 & 0.89 & 0.88 \\
\hline $\mathrm{K}_{3} \mathrm{~S}_{2} \mathrm{~T}_{2}$ & 50.59 & 53.72 & 52.16 & 59.47 & 61.32 & 60.40 & 0.85 & 0.88 & 0.87 \\
\hline $\mathrm{K}_{4} \mathrm{~S}_{1} \mathrm{~T}_{1}$ & 49.93 & 54.13 & 52.03 & 57.81 & 61.34 & 59.57 & 0.86 & 0.88 & 0.87 \\
\hline $\mathrm{K}_{4} \mathrm{~S}_{1} \mathrm{~T}_{2}$ & 50.53 & 54.36 & 52.44 & 58.59 & 62.11 & 60.35 & 0.86 & 0.88 & 0.87 \\
\hline $\mathrm{K}_{4} \mathrm{~S}_{2} \mathrm{~T}_{1}$ & 50.64 & 54.59 & 52.62 & 58.43 & 62.06 & 60.24 & 0.87 & 0.88 & 0.88 \\
\hline $\mathrm{K}_{4} \mathrm{~S}_{2} \mathrm{~T}_{2}$ & 51.13 & 55.25 & 53.19 & 60.33 & 62.86 & 61.59 & 0.85 & 0.88 & 0.87 \\
\hline $\mathrm{K}_{5} \mathrm{~S}_{1} \mathrm{~T}_{1}$ & 50.72 & 53.98 & 52.35 & 58.39 & 59.74 & 59.07 & 0.87 & 0.90 & 0.89 \\
\hline $\mathrm{K}_{5} \mathrm{~S}_{1} \mathrm{~T}_{2}$ & 52.06 & 55.16 & 53.61 & 59.74 & 60.47 & 60.11 & 0.87 & 0.91 & 0.89 \\
\hline $\mathrm{K}_{5} \mathrm{~S}_{2} \mathrm{~T}_{1}$ & 52.19 & 56.61 & 54.40 & 59.56 & 63.08 & 61.32 & 0.88 & 0.90 & 0.89 \\
\hline $\mathrm{K}_{5} \mathrm{~S}_{2} \mathrm{~T}_{2}$ & 52.89 & 56.78 & 54.83 & 60.65 & 63.40 & 62.02 & 0.87 & 0.90 & 0.89 \\
\hline S.Em \pm & 0.83 & 0.46 & 0.46 & 1.02 & 0.80 & 0.61 & 0.02 & 0.01 & 0.01 \\
\hline C.D. $(p=0.05)$ & NS & NS & NS & NS & NS & NS & NS & NS & NS \\
\hline
\end{tabular}

DAT - Days after transplanting, NS-Non significant.

Note: Recommended dose of N:P at 125:75 kg and farmyard manure $30 \mathrm{t} \mathrm{ha}^{-1}$ was applied commonly to all the treatments and nitrogen was applied $50 \%$ at transplanting and $50 \%$ at 30 DAT. 
Table 3: Split bulbs and harvest index (\%) of onion var. Arka Kalyan as influenced by the soil application of potassium levels, sources and time of application during kharif season

\begin{tabular}{|c|c|c|c|c|c|c|}
\hline \multirow{2}{*}{ Treatment } & \multicolumn{3}{|c|}{ Split bulbs (\%) } & \multicolumn{3}{|c|}{ Harvest index (\%) } \\
\hline & 2015 & 2016 & Pooled & 2015 & 2016 & Pooled \\
\hline \multicolumn{7}{|l|}{\begin{tabular}{|l|} 
Potassium levels (k) \\
\end{tabular}} \\
\hline $\mathrm{K}_{1}-100 \% \mathrm{RDK}$ & 8.29 & 9.16 & 8.72 & 84.75 & 88.85 & 86.80 \\
\hline $\mathrm{K}_{2}-125 \% \mathrm{RDK}$ & 10.91 & 10.70 & 10.81 & 84.00 & 88.54 & 86.27 \\
\hline $\mathrm{K}_{3}-150 \% \mathrm{RDK}$ & 14.05 & 12.20 & 13.13 & 83.52 & 88.10 & 85.81 \\
\hline $\mathrm{K}_{4}-175 \% \mathrm{RDK}$ & 12.33 & 11.82 & 12.08 & 82.35 & 86.77 & 84.56 \\
\hline $\mathrm{K}_{5}-200 \% \mathrm{RDK}$ & 12.41 & 11.50 & 11.95 & 80.53 & 85.43 & 82.98 \\
\hline S.Em \pm & 1.34 & $\mathbf{0 . 8 0}$ & $\mathbf{1 . 0 3}$ & $\mathbf{0 . 4 0}$ & $\mathbf{0 . 1 7}$ & 0.25 \\
\hline C.D. $(p=0.05)$ & NS & NS & 2.95 & 1.13 & 0.49 & 0.72 \\
\hline \multicolumn{7}{|l|}{ Potassium sources $(\mathrm{S})$} \\
\hline $\mathrm{S}_{1}-$ Muriate of potash (MOP) & 11.11 & 11.16 & 11.13 & 83.21 & 87.62 & 85.42 \\
\hline $\mathrm{S}_{2-}$ Sulphate of potash (SOP) & 12.09 & 11.00 & 11.54 & 82.85 & 87.45 & 85.15 \\
\hline S.Em \pm & 0.85 & 0.50 & 0.65 & 0.25 & 0.11 & 0.16 \\
\hline C.D. $(p=0.05)$ & NS & NS & NS & NS & NS & NS \\
\hline \multicolumn{7}{|l|}{ Time of application (T) } \\
\hline $\mathrm{T}_{1}-100 \% \mathrm{~K}$ a transplanting & 11.47 & 10.05 & 11.26 & 82.99 & 87.54 & 85.26 \\
\hline $\begin{array}{l}\mathrm{T}_{2^{-}} 50 \% \mathrm{k} \text { at transplanting } \& 50 \% \mathrm{~K} \text { at } 30 \\
\text { DAT }\end{array}$ & 11.72 & 11.10 & 11.41 & 83.06 & 87.54 & 85.30 \\
\hline S.Em \pm & $\mathbf{0 . 8 5}$ & $\mathbf{0 . 5 0}$ & 0.65 & $\mathbf{0 . 2 5}$ & 0.11 & 0.16 \\
\hline C.D. $(p=0.05)$ & NS & NS & NS & NS & NS & NS \\
\hline \multicolumn{7}{|l|}{ Interactions } \\
\hline $\mathrm{K}_{1} \mathrm{~S}_{1} \mathrm{~T}_{1}$ & 7.31 & 9.67 & 8.49 & 84.96 & 88.72 & 86.84 \\
\hline $\mathrm{K}_{1} \mathrm{~S}_{1} \mathrm{~T}_{2}$ & 6.73 & 9.19 & 7.96 & 85.23 & 88.94 & 87.09 \\
\hline $\mathrm{K}_{1} \mathrm{~S}_{2} \mathrm{~T}_{1}$ & 10.28 & 8.76 & 9.52 & 83.78 & 88.86 & 86.32 \\
\hline $\mathrm{K}_{1} \mathrm{~S}_{2} \mathrm{~T}_{2}$ & 8.84 & 9.02 & 8.93 & 85.01 & 88.87 & 86.94 \\
\hline $\mathrm{K}_{2} \mathrm{~S}_{1} \mathrm{~T}_{1}$ & 9.49 & 8.65 & 9.07 & 83.98 & 88.62 & 86.30 \\
\hline $\mathrm{K}_{2} \mathrm{~S}_{1} \mathrm{~T}_{2}$ & 14.77 & 13.36 & 14.07 & 83.89 & 88.34 & 86.11 \\
\hline $\mathrm{K}_{2} \mathrm{~S}_{2} \mathrm{~T}_{1}$ & 10.90 & 10.86 & 10.88 & 83.95 & 88.48 & 86.21 \\
\hline $\mathrm{K}_{2} \mathrm{~S}_{2} \mathrm{~T}_{2}$ & 8.50 & 9.95 & 9.23 & 84.19 & 88.73 & 86.46 \\
\hline $\mathrm{K}_{3} \mathrm{~S}_{1} \mathrm{~T}_{1}$ & 14.00 & 13.13 & 13.56 & 83.40 & 87.95 & 85.68 \\
\hline $\mathrm{K}_{3} \mathrm{~S}_{1} \mathrm{~T}_{2}$ & 16.24 & 14.77 & 15.50 & 83.12 & 88.26 & 85.69 \\
\hline $\mathrm{K}_{3} \mathrm{~S}_{2} \mathrm{~T}_{1}$ & 14.87 & 12.34 & 13.61 & 83.62 & 88.14 & 85.88 \\
\hline $\mathrm{K}_{3} \mathrm{~S}_{2} \mathrm{~T}_{2}$ & 11.11 & 8.57 & 9.84 & 83.93 & 88.03 & 85.98 \\
\hline $\mathrm{K}_{4} \mathrm{~S}_{1} \mathrm{~T}_{1}$ & 10.59 & 10.33 & 10.46 & 82.85 & 86.63 & 84.74 \\
\hline $\mathrm{K}_{4} \mathrm{~S}_{1} \mathrm{~T}_{2}$ & 10.33 & 10.09 & 10.21 & 82.97 & 87.07 & 85.02 \\
\hline $\mathrm{K}_{4} \mathrm{~S}_{2} \mathrm{~T}_{1}$ & 15.33 & 14.44 & 14.88 & 82.04 & 86.90 & 84.47 \\
\hline $\mathrm{K}_{4} \mathrm{~S}_{2} \mathrm{~T}_{2}$ & 13.07 & 12.42 & 12.75 & 81.53 & 86.49 & 84.01 \\
\hline $\mathrm{K}_{5} \mathrm{~S}_{1} \mathrm{~T}_{1}$ & 9.06 & 10.78 & 9.92 & 80.92 & 85.80 & 83.36 \\
\hline $\mathrm{K}_{5} \mathrm{~S}_{1} \mathrm{~T}_{2}$ & 12.59 & 11.59 & 12.09 & 80.81 & 85.90 & 83.35 \\
\hline $\mathrm{K}_{5} \mathrm{~S}_{2} \mathrm{~T}_{1}$ & 12.96 & 11.53 & 12.24 & 80.41 & 85.31 & 82.86 \\
\hline $\mathrm{K}_{5} \mathrm{~S}_{2} \mathrm{~T}_{2}$ & 15.04 & 12.07 & 13.56 & 79.99 & 84.72 & 82.36 \\
\hline S.Em \pm & 2.67 & 1.60 & 2.06 & 0.79 & 0.34 & 0.50 \\
\hline C.D. $(p=0.05)$ & NS & NS & NS & NS & NS & NS \\
\hline
\end{tabular}

DAT - Days after transplanting, NS-Non significant.

Note: Recommended dose of N:P at $125: 75 \mathrm{~kg}$ and farmyard manure $30 \mathrm{t} \mathrm{ha}^{-1}$ was applied commonly to all the treatments and nitrogen was applied $50 \%$ at transplanting and $50 \%$ at 30 DAT.

\section{REFERENCES}

1. Vavilov, N. I., Origin, variation, immunity and breeding of cultivated plants. $J$. Chronical Bot., 13(1/6): 1-364 (1951).
2. Anonymous, Indian Horticultural Database (2015). www.nhb.gov.in.

3. McGillivary, J. H., Vegetable production. Mc Grew Hill Book Co. Inc. New York, pp.169-273 (1961). 
4. Pachauri, S. P., Singh, V. and Pachauri, C. P., Effect of FYM, nitrogen and potassium on growth, yield and quality of onion. Ann. Pl. Soil Res., 7(1): 54-56 (2005).

5. Engels, C., Kirkby, E. A. and White, P., Mineral nutrition, yield and source sink relationships. In: Marschner, P. (ed.) Marschner's mineral nutrition of higher plants, $3^{\text {rd }}$ edition. Elsevier Ltd. pp. 85-97 (2012).

6. Hawkesford, M., Horst, W., Kichey, T., Lambers, H., Schjoerring, J., Skrumsager, M. I. and White, P., Functions of macronutrients. In: Marshner, P. (ed.) Marschner's Mineral Nutrition of Higher Plants, $3^{\text {rd }}$ edition. Elsevier Ltd., pp. 135151 (2012).

7. Hariyappa, N., Effect of potassium and sulphur on growth, yield and quality parameters of onion (Allium cepa L.). $M$. Sc. Thesis, Univ. of Agric. Sci., Dharwad (India) 2003.

8. Girigowda, J. R., Narasegowda, N. C. and Krishna, H. C., Effect of fertilizer levels on uptake of primary nutrients and bulb yield of onion hybrids. Mysore J. Agric. Sci. 39(4): 557-560 (2005).

9. Barman, H. K., Siddiqui, M. N., Siddique, M. A., Roni, M. S. and Nuruzzaman, M., Combined effect of organic manure and potassium on growth and yield of onion cv. Bari piaz-i. Int. J. Agric. Res. Innov. Tech., 3(1): 47-51 (2013).
10. Deshpande, A. N., Dage, A. R., Bhalerao, V. P. and Bansal, S. K., Potassium nutrition for improving yield and quality of onion. Int. Potash Institute, 36: 214-222 (2013).

11. Desuki, M. M., Abdel-Mouty and Ali, A. $\mathrm{H}$., Response of onion plants to additional dose of potassium application. J. Appl. Sci. Res., 2(9): 592-597 (2006).

12. Ghulamnabi, Abdur, R., Sayed, J. A., Farhatullah, Fazal, M. and Ibrar, H. S., Influence of different levels of potash on the quantity, quality and storage life of onion bulbs. Pakistan J. Bot., 42(3): 215219 (2010).

13. Singh, S. P. and Verma, A. B., Response of onion (Allium cepa) to potassium application. Indian J. Agron., 46(1): 182185 (2001).

14. Lee JongTae, Ha-InJong, Lee-Chan, Moon-Jin, S. and Cho-Yong, C., Effect of $\mathrm{N}, \mathrm{P}_{2} \mathrm{O}_{5}$, and $\mathrm{K}_{2} \mathrm{O}$ application rates and top dressing time on growth and yield of onion (Allium cepa L.) under spring culture in low land. Korean J. Hort. Sci. Technol., 21(4): 260-266 (2003).

15. Islam, M. A., Sharnsuddoha, A. T. M, Bhuiyan, M. S. I. and Hasanmzaman, M., Response of summer onion to potash and its application methods. American. Eurasian J. Agron., 1(1): 10-15 (2008). 